\title{
PEMAPARAN DAN FOCUS GROUP DISCUSSION : UPAYA PERUMUSAN STRATEGI PEMBINAAN PASAR RAKYAT DALAM MENGHADAPI PUSAT PERBELANJAAN DAN TOKO SWALAYAN
}

\author{
Muafi \\ Dosen Manajemen FE Universitas Islam Indonesia \\ Email: muafi@uii.ac.id
}

\begin{abstract}
ABSTRAK
Hadirnya pasar modern (pusat perbelanjaan dan toko swalayan) dianggap telah menyudutkan keberadaan dari pasar rakyat baik di daerah perkotaan maupun pedesaan (sub urban). Keberadaannya yang terus bertambah, apalagi dibangun terintegrasi dengan fasilitas umum lain seperti stasiun, terminal, hotel, ataupun apartemen, membuat pasar modern diminati dan menjadi pilihan utama bagi konsumen untuk berbelanja. Meskipun demikian pasar rakyat juga memiliki keunggulan yang tidak kalah menarik dibandingkan dengan pasar modern. Keduanya harus saling melengkapi dan bersinergi satu sama lainnya. Oleh karena itu diperlukan upaya untuk merumuskan strategi dan kebijakan yang diharapkan bisa diimplementasikan dengan baik oleh stakeholders utama (pemerintah, pelaku bisnis, pengelola usaha).
\end{abstract}

Kata kunci: pasar tradisional, pasar modern, stakeholders, strategi

\begin{abstract}
The existence of modern market (shopping center and supermarket) considered have been cornered the existence of traditional market, either urban area or suburban area. Its ever-growing existence, which also added with other public facility such as station, terminal, hotel, or even apartment, make the modern market in demand and become the main choices for consumer to shop. Even so, traditional market has its own excellence that is no less interesting than modern market. Both of these markets have to complete and synergize each other. That is why it needed an effort to frame the strategy and policy that is expected to implement by the main stakeholder (government, businessman, business manager).
\end{abstract}

Key word: traditional market, modern market, stakeholders, strategy 


\section{PENDAHULUAN}

Tidak bisa dipungkiri bahwa keberadaan pasar modern saat ini sudah menjadi tuntutan dan gaya hidup modern yang berkembang di masyarakat. Kondisi ini tidak hanya terjadi di kota-kota besar atau metropolitan tetapi sudah merambah sampai kota kecil di Indonesia (suburban). Di beberapa tempat baik di perkotaan maupun pedesaan akan sangat mudah menjumpai minimarket, supermarket bahkan hypermarket. Tempat-tempat tersebut menjanjikan tempat belanja yang nyaman dengan harga menarik bagi konsumen.Merebaknya toko modern di berbagai daerah di DIY, merupakan fenomena yang terjadi dan harus disikapi dengan arif, karena apabila suatu daerah tidak hati-hati didalam mengambil suatu kebijakan, maka akan menjadi preseden negatif dimasa yang akan datang.

Seperti diketahui, pasar tradisional merupakan pasar yang dibangun dan dikelola oleh Pemerintah, Pemerintah Daerah, Swasta, Badan
Usaha Milik Negara dan Badan Usaha Milik Daerah termasuk kerjasama dengan swasta dengan tempat usaha berupa toko, kios, los dan tenda yang dimiliki/dikelola oleh pedagang kecil, menengah, swadaya masyarakat atau koperasi dengan usaha skala kecil, modal kecil serta proses jual beli barang dagangan melalui tawar menawar (PeraturanMenteriPerdagangan $\quad \mathrm{RI}$ nomor 53 tahun 2008).Hadirnyapasar modern baik dalam bentuk supermarket, hypermarket atau minimarket telah dianggap menyudutkan keberadaan dari pasar tradisiona I(saat ini disebut pasar rakyat) di daerah perkotaan. Keberadaannya yang terus bertambah, apalagi dibangun terintegrasi dengan fasilitas umum lain seperti stasiun, terminal, hotel, ataupun apartemen, membuat tempat belanja satu ini diminati dan menjadi pilihan utama (https://ekbis.sindonews.com, 2017). Kehadiran dari pasar modern saat ini memberikan pengaruh terhadap penurunan kontribusi dan kinerja dari pasar rakyat. Hal ini lebih diakibatkan 
dari pengaruh faktor internal pasar strategi pasar rakyat dalam menghadapi rakyat yang menyebabkan daya saing berkurang (Suryadarmadkk, 2007). pasar modern (pusat perbelanjaan dan Merebaknya toko modern tidak hanya took swalayan). Perumusan strategi tersebut dilakukan dengan kegiatan terjadi pada skala nasional. DIY sebagai pengabdian masyarakat melalui salah satu wilayah dengan kontribusi pemaparan materi dan Focus Group sector perdagangan yang besar Discussion (FGD) dengan peserta yang terhadap PDRB menghadapi hal dihadiri oleh pajabat pemerintah serupa.Pada tahun 2010 jumlah toko setempat. Sebelum diakukan FGD modern di Provinsi DIY telah mencapai pemateri diminta untuk memaparkan 405 unit yang tersebar di 5 tentang kajian Manajemen Strategi Kabupaten/Kota. Secara total sebagai salah satu wujud kegiatan pertumbuhan toko modern di DIY pengabdian masyarakat yang dilakukan selama 2005-2010 tidak kalah tinggi oleh pengabdi.

dengan nasional dan bahkan lebih tinggi yaitu $187,23 \%$ dengan angka rata-rata pertumbuhan setiap tahunnya sebesar 19,54\%. Pasar tradisional sebagai pasar rakyat yang tumbuh dari cirri khas budaya di Indonesia yang mengedepankan prinsip kerakyatan, kegotong-royongan dan Bhineka Tunggal Ika, maka sudah sepatutnya harus dilestarikan dan dipertahankan keberlangsungannya (Biro Administrasi Perekonomian Dan SumberDaya Alam Sekretariat Daerah, DIY. 2017). Oleh karena itu, diperlukan perumusan

\section{METODE/APLIKASI}

Metode pengabdian masyarakat yang dilakukan pengabdi dalam hal ini adalah; pemaparan dengan pemberian materi dan diskusi dengan teknis FGD. Pemaparan dilakukan dengan memberikan wacana ilmu dan pengetahuan tentang pentingnya melakukan perumusan strategi pasar rakyat dalam menghadapi pasar modern (pusat perbelanjaan dan toko swalayan) sehingga bisa mengimplementasikan strategi pada 
masing-maisng pihak yang terlibat. selanjutnya dapat digunakan sebagai Pemaparan dilakukan selama 1,5 jam. dasar untuk merancang strategi dan Selanjutnya dilanjutkan dengan Focus program kerja dari suatu organisasi. Group Discussion (FGD) selama 2 jam. Analisis lingkungan internal meliputi Masing-masing peserta memberikan peniaian terhadap faktor kekuatan masukan sekaligus pertanyaan untuk (strength) dan kelemahan (weakness) didiskusikan dan dicarikan solusinya. yang dimiliki oleh organisasi. Peserta FGD yang hadir di dalam forum Sementara, analisis lingkungan tersebut adalah Kementerian Perdagangan dalam negeri RI, Asisten Perekonomian dan Pembangunan Setda DIY, Kepala Bapeda DIY, dan beberapa pejabat dan staf terkait di DIY.

\section{HASIL DAN PEMBAHASAN}

Berdasarkan hasil pemaparan dan focus group discussion dengan peserta. Pemateri menyampaikan materi yang dikumpulkan dari berbagai literature (Sarwoko, 2008; Rahayu dan Fitanto, 2013; Susanti, dkk, 2014).S elanjutnnya dilakukan analisis SWOT antara pasar rakyat dengan pasar modern (pusat perbelanjaan dan took swalayan). Analisis SWOT adalah metode perencanaan strategis yang mencakup analisis kondisi internal maupun eksternal suatu organisasi yang eksternal mencakup faktor peluang (opportunity) dan tantangan (threaths) yang dihadapi oleh organisasi. Organisasi perlu melakukan identifikasi peluang dan ancaman yang dihadapi serta kekuatan dan kelemahan yang dimiliki organisasi terhadap lingkungan operasi dan kepemilikan sumberdaya dalam merumuskan strategi organisasi yang realistis dalam mewujudkan misi dan visi organisasi. Hal ini bisa memberikan manfaat agar bisa mengimplementasikan strategi dan kebijakan yang tepat bagi para stakeholders dalam mencapai tujuan organisasi dan peningkatan kinerja organisasi (Glueck dan Jauch, 1991; David, 2001). Hasil analisis SWOT untuk pasar rakyat dan pasar modern dilakukan sebagai berikut: 


\section{PASAR RAKYAT}

\section{Kekuatan}

1. Harga yang lebih murah Harga yang ditawarkan oleh pasar rakyat untuk produk-produknya relatif lebih murah dan terjangkau oleh masyarakat kalangan bawah dibandingkan dengan pasar modern. Adanya harga murah ini tidak akan pernah dijumpai di pasar modern dan menjadi daya tarik yang sangat kuat.

2. Modal sosial

Penjual dan konsumendi pasar rakyat relatif telah saling mengenal satu sama lain. Mereka biasanya memiliki ikatan emosional yang kuat dan adanya ikatan kekeluargaan. Rata-rata konsumen dan penjual berada dalam lingkungan masyarakat yang sama bahkan bersaudara satu sama lain. Mereka memiliki ikatan yang kuat di lingkungan RT seperti kegiatan arisan, posyandu, dan pengajian serta kegiatan sosial lainnya.

3. Kegiatan tawar menawar
Kegiatan tawar menawar merupakan suatu kegiatan yang sangat identik dengan pasar tradisional dan menjadi daya tarik yang sangat bagus. Kegiatan ini tidak akan pernah dapat ditemui di pasar modern. Adanya kepuasan yang diperoleh oleh konsumenjika memperoleh harga yang murah menjadikan konsumen memiliki loyalitas yang tinggi. Disamping itu juga biasanya akan tercipta lingkungan yang akrab antara konsumen dan penjual.

4. Produk yang dijual cukup bervariasi

Produk yang dijual di pasar tradisional memiliki variasi. Adanya beberapa kios terbagi pada bagianbagian tertentu untuk setiap kategori kebutuhan pokok, seperti kios beras dan kebutuhan sembako, kios sayur mayur, kios buah-buahan, kios bagian daging segar, dan kios lainnya.

5. Lokasi yang dekat dan terjangkau

Lokasi pasar tradisional biasanya relatif dekat dengan lingkungan sekitar masyarakat dan hampir ada 
di setiap kecamatan di suatu daerah.Konsumen tidak lagi mengeluarkan ongkos transportasi yang cukup mahal untuk menjangkau pasar tersebut.

\section{Kelemahan}

1. Kesan kumuh dan becek

Pasar rakyat selalu dipersepsikan kumuh dan becek baik dari aspek lingkungan dan sarana prasarananya. Kondisi ini mempengaruhi konsumen malas, khususnya kalangan menengah untuk berbelanja di pasar rakyat.

2. Kondisi Fisik Pasar Rakyat Kurang Memadai,

Ada beberapa pasar rakyat yang memiliki bangunan fisik kurang memadai dan tidak terawat karena biasanya merupakan bangunan peninggalan jaman Belanda.

3. Harga yang tidak stabil Harga yang didapatkankonsumen kadangkala malah lebih mahal dibandingkan dengan pasar modern. Hal ini dikarenakan adanya proses tawar menawar dan konsumen kadangkala tidak mengetahui dengan pasti harga yang sebenarnya.

4. Fasilitas sarana prasarana yang kurang

Konsumen kadangkala merasakan adanya fasilitas sarana prasarana yang masih sangat kurang khususnya dari aspek kebersihan, jalan yang sempit dan becek, lingkungan yang panas, toilet yang kotor dan fasilitas lainnya.

5. Keamanan pasar tradisional

Faktor keamanaan juga menjadi salah satu tolok ukur kosumen untuk malas berbelanja di pasar tradisional. Seringkali masih dijumpai jika berbelanja di pasar rakyat terjadi tindakan pencopetan, perkelahian, pemalsuan dan tindakan kriminal lainnya.

6. Produk yang tidak standar dan tidak modern

Tidak adanya standarisasi produk baik dari aspek kuantitas maupun kualitas menjadikan pasar rakyat tidak lagi digemari oleh anak-anak muda. Juga produk yang dijual relatif 
tidak populer dan update dengan kebutuhan anak-anak muda. Belum lagi masih banyak ditemui produkproduk yang tidak asli dan produkproduk yang masih mengandung bahan kimia berbahaya.

\section{Peluang}

1. Kebijakan pemerintah dalam mempertahankan keberadaan pasar rakyat. Adanya beberapa peraturan pemerintah yang mendukung pasar rakyat disamping target NAWACITA Presiden RI untuk memiliki 5000 pasar rakyat dalam RPJM 20152019.

2. Revitalisasi pasar rakyat, dapat menjadi peluang bagi pasar rakyat untuk bersaing dengan pasar modern. Pemerintah memiliki komitmen untuk melakukan revitalisasi pasar rakyat dalam hal sarana dan prasarana juga pengelolaan pasar rakyat.

3. Pemenuhan kebutuhan dan keinginan masyarakat kalangan menengah ke bawah pada pasar rakyat. Pasar rakyat masih sangat dibutuhkan keberadaannya oleh masyarakat kalangan menengah dan bawah karena pasar rakyat jauh lebih memiliki nilai ekonomis di masyarakat di bandingkan dengan pasar modern.

4. Peningkatan pertumbuhan ekonomi masyarakat Masyarakat memiliki peluang menjadi pelaku usaha di pasar tradisonal dengan modal yang relatif bisa dijangkau. Demikian juga konsumen bisa membeli produk dan layanan di pasar rakyat dengan harga yang terjangkau. Adanya transaksi bisnis ini diharapkan akan bisa meningkatkan pertumbuhan ekonomi masyarakat yang saling bersinergi satu sama lainnya..

\section{Ancaman}

1. Pertumbuhan pasar modern yang terus meningkat

Adanya pasar modern yang semakin meningkat menandakan bahwa peluang untuk menambah segmentasi pasar rakyat beralih ke 
pasar modern semakin mengkhawatirkan. Kalangan muda khususnya sudah jarang dijumpai bertransaksi di pasar rakyat. Demkian juga kalangan keluarga muda metropolis (ibu dan bapak muda generasi milineal) semakin malas untuk berbelanja di pasar rakyat. Situasi dan kondisi ini lambat laun akan bisa mengancam keberadaan pasar rakyat. Apalagi jika pasar rakyat tidak ditunjang dengan fasilitas sarana dan prasarana yang lengkap dan modern. Dikhawatirkan akan semakin mengurangi konsumen dari masyarakat menengah ke atas untuk bertransaksi di pasar rakyat.

2. Pasar Online.

Saat ini semakin maraknya pasar online untuk melayani masyarakat yang sibuk, malas untuk keluar, ingin bertransaksi cepat dan efisien. Apalagi jika masyarakat hidup di kota-kota modern dan metropolitan. Peluang ini ditangkap oleh pasar online. Bahkan saat ini transaksi lewat online tidak hanya melayani kebutuhan primer dan sekunder, tetapi juga melayani kebutuhan tersier.

3. Tidak stabilnya harga produk di pasar rakyat

Harga produk di pasar rakyat seringkali tidak stabil. Meskipun tidak terlalu besar perubahannya tetapi kondisi ini memberikan dampak yang sangat signifikan untuk konsumen dari kalangan menengah ke bawah. Mereka malah semakin malas untuk bertransaksi di pasar rakyat dan akan cepat beralih untuk bertransaksi di pasar modern (swalayan).

4. Kualitas produk dan standarisasi produk

Masyarakat dari kalangan menengah ke bawah saat ini semakin kritis dan cerdas dalam membeli suatu produk khususnya dari aspek harga dan kualitas. Mereka akan membeli produk dengan kualitas bagus dan terstandarisasi meskipun dengan 
harga yang sedikit mahal, daripada produk yang murah tetapi kualitas yang dimiliki produk tersebut rendah dan tidak memiliki standar.

5. Promosi

Strategi promosi yang dilakukan oleh pasar rakyat sangat lemah dan kurang. Sementara pasar modern memiliki strategi promosi yang sangat gencar, bahkan sampai menyebarkan leaflet dan selebaran ke desa-desa dan daerah sub urban. Hal ini dikhawatirkan bisa mempengaruhi konsumen pasar rakyat untuk beralih berbelanja di pasar modern. Apalagi mereka siap dengan layanan antar jemput produk ke konsumen meskipun berada di area yang jauh.

6. Keahlian dan Pengetahuan

Tuntutan dan gaya hidup konsumen memiliki perubahan yang sangat cepat seiring dengan perkembangan lingkungan bisnis. Hal ini menuntut pengetahuan dan keahlian dari pedagang pasar, pengeloa pasar dan pemerintah untuk terus berbenah dalam mengelola pasar rakyat. Jika tidak maka akan semakin jauh tertinggal dan kalah bersaing dengan hadirnya pasar modern.

7. Perkembangan teknologi

Tuntutan teknologi yang terus bergerak cepat menuntut pasar rakyat untuk terus belajar dan mengikuti dan menggunakannya dengan tepat. Konsumen saat ini dihadapkan pada teknologi yang modern dan canggih sehingga akan bisa lebih memiliki pilihan untuk bertransaksi dengan cepat dan efisien.

\section{PASAR MODERN DAN SWALAYAN}

\section{Kekuatan}

1. Pelayanan dan fasilitas berbelanja Pasar modern menawarkan pelayanan dan fasilitas berbelanja yang bagus dan nyaman. Disamping itu adanya rasa aman dalam berbelanja serta didukung dengan pelayanan yang memuaskan. Pembayaran bisa dilakukan melalui transaksi tunai dan lewat kartu kredit. Fasilitas 
seperti toilet dan mainan anakanak semakin membuat konsumen betah berbelanja di pasar modern,

2. Kelengkapan dan kualitas serta standarisasi tertentu

Kelengkapan produk yang ada di pasar modern dan memiliki standarisasi menjadi pertimbangan bagi konsumen untuk berbelaja di pasar modern. Hal ini semakin menambah keyakinan bagi konsumenterhadap pasar modern disamping adanya faktor gengsi jika berbelanja di pasar modern.

3. Strategi promosi

Pasar modern menawarkan strategi promosi yang bervariasi dan menarik. Misalnya discount, layanan siap antar, layanan 24 jam dan lainnya sehingga strategi ini dapat dijadikan sebagai kekuatan dari pasar modern untuk menarik konsumen agar datang dan berbelanja.

4. Hubungan yang baik dengan supplier

Tidak bisa dipungkiri banhwa supplier memberikan kekuatan bagi pasar modern untuk memenuhi kebutuhan konsumennya. Hal ini memberikan kekuatan bagi pasar modern dalam hal harga dan kepastian dari ketersediaan barang dari supplier.

5. Lokasi mudah dijangkau dan strategis

Lokasi dari pasar modern biasanya memiliki aksesa yang mudah dijangkau dan strategis karena biasanya terletak di pinggir jalan yang bagus. Hal ini menjadikan pasar modern memiliki daya jual yang menarik bagi konsumen.

6. Modal yang dimiliki besar

Modal yang dimiliki oleh pemilik pasar modern kuat dan besar sehingga mereka bisa menciptakan semua fasilitas dan sarana prasarana yang lebih bis mengakomodasikan kebutuhan dan keinginan konsumen serta kepuasan yang maksimal.

7. Kecepatan. Kemudahan dan kenyaman dalam pelayanan Pelayanan yang cepat dan mudah serta nyaman diberikan oleh pasar 
modern agar konsumen semakin senang untuk bertransaksi dan kembali lagi bertransaksi karena pengalaman berbelanja yang menyenangkan. Pasar modern juga didukung dengan teknologi informasi yang memungkinkan konsumen bisa memanfaatkannya dengan baik dan aman serta dapat menghemat waktu.

\section{Kelemahan}

1. Harga lebih mahal

Persepsi masyarakat terhadap harga produk yang dijual di pasar modern adalah mahal. Hal ini bisa dikarenakan produk yang ditawarkan di asosiasikan memiliki kualitas yang lebih baik dibandingkan dengan pasar rakyat dan harganya tidak bisa ditawar.

2. Tidak semua produk tersedia di pasar modern

Tidak semua produk yang diperlukan oleh konsumen dapat tersedia di pasar modern. Hal ini dikarenakan di pasar modern kurang bisa memahami kebutuhan masyarakat sesuai dengan kearifan lokal sekitar sehingga produk yang dijual cenderung produk modern dan berstandar global.

3. Promosi yang menjenuhkan Promosi yang ditawarkan oleh pasar modern menjenuhkan dan terlalu bombastis sehingga membuat masyarakat bosan dan merasa di bohongi. Meskipun harganya sudah di discount tapi konsumen tetap beranggapan harganya masih sangat mahal dan hanya bisa terjangkau oleh konsumen menengah ke atas.

\section{PELUANG}

1. Perluasan pasar dan ekspansi

Pasar modern memiliki peluang yang lebih besar untuk berkembang lebih pesat daripada pasar rakyat. Hal ini karena potensi masyarakat urban yang terus bertambah sehingga merupakan calon potensi konsumen yang akan memberikan kontribusi besar. Demikian juga pemilik modal dari pasar modern memiliki modal yang 
kuat sehingga akan semakin memperluas pasar nya dan melakukan ekspansi ke lokasi dimana memiliki pangsa pasar yang potensial untuk dilayani.

2. Tambahan modal usaha

Pemilik pasar modern memiliki peluang yang sangat besar untuk memperoleh tambahan modal usaha sehingga akan dengan mudah melakukan ekspansi atau mengembangkan pasarnya. Kepercayaan dari stakeholders menjadikan modal utama bagi pasar modern untuk terus mengembangkan usahanya

\section{Pertumbuhan ekonomi}

Pertumbuhan ekonomi masyarakat yang meningkat akan dapat memberikan peluang yang bagus bagi pasar modern. Biasanya ditandai dengan adanya daya beli masyarakat yang semakin meningkat dan tidak sensitif terhadap harga. Kondisi ini akan semakin memberikan peluang bagi pasar modern untuk berkembang.
4. Perkembangan teknologi

Perkembangan teknologi yang terjadi serta modal usaha yang dimiliki oleh pelaku bisnis pasar modern akan memberikan peluang bagi pasar modern untuk mengadopsi teknologi terbaru yang bisa dijadikan untuk memberikan kemudahan dan layanan kepada konsumen. Disamping itu pasar modern akan bisa beroperasi dengan lebih efektif dan efisien.

5. Perluasan jaringan supplier Reputasi pasar modern akan semakin meningkatkan kepercayaan bagi supplier untuk menjadi rekanannya. Supplier dapat dengan mudah diperoleh oleh pasar modern sehingga jaringan supplier yang cukup luas dan banyak dapat memberikan peluang bagi pasar modern untuk memiliki posisi tawar yang sangat kuat sehingga bisa menjual produknya dengan harga yang sangat bisa bersaing dengan pasar rakyat. 


\section{ANCAMAN}

1. Persaingan di pasar modern yang semakin meningkat

Tidak dapat dipungkiri bahwa pemain pasar modern semakin banyak dan kompeitif. Hal ini akan mengakibatkan adanya ancaman dalam jangka panjang. Mereka saling berebut untuk memperoleh konsumen yang potensial. Disamping itu, pasar modern bersaing juga dengan pasar tradisional yang semakin baik dari aspek harga dan pelayanannya.

2. Kebijakan pemerintah dalam membatasi pasar modern

Saat ini pemerintah masih sangat peduli dan memperhatikan keberadaan pasar rakyat yang dirasakan masih sangat membantu masyarakat kalangan bawah. Oleh karena itu, pemerintah saat ini membuat peraturan dan kebijakankebijakan yang dapat membatasi gerak da proses operasi dari pasar modern. Hal ini dilakukan harapannya agar antara pasar rakyat dan pasar modern bisa berjalan beriringan dan bersinergi satu sama lain.

3. Revitalisasi pasar rakyat

Pemerintah telah melakukan revitalisasi pasar rakyat baik dari aspek fisik dan non fisik dengan tujuan agar memberikan pelayanan yang lebih baik bagi konsumen. Sarana dan prasarana terus ditingkatkan karena jika tidak akan dapat memberikan suatu ancaman yang besar bagi pasar rakyat. Diharapkan konsumen pasar modern akan banyak beralih ke pasar rakyat karena telah memiliki sarana dan prasarana juga keamanan dan kenyamanan yang hampir sama dengan pasar modern, disamping di pasar rakyat memiliki keunggulan yakni faktor harga yang lebih murah dan lokasi yang bisa terjangkau.

Berdasarkan analisis SWOT yang telah dilakukan, maka diskus idilanjutkan dengan merumuskan strategi dan kebijakan untuk pembinaan pasar rakyat, pusat perbelanjaan dan took 
swalayan yang menunjang sector perdagangan sehingga bisa memberikan daya saing dan saling menguntungkan kedua belah pihak. Ada tiga pihak yang memiliki keterkaitan antara satu dengan lainnya dan harus saling memberikan dukungan. Diantaranya adalah; pihak penjual, pihak pengelola pasar, dan pihak pemerintah.

\section{PIHAK PENJUAL}

a. Kualitas produk yang bagus

Pedagang pasar rakyat akan bisa bersaing jika bisa menjual produknya dengan kualitas yang bagus. Tidak adanya standarisasi dan kemasan produk yang kurang menarik dan higenis membuat konsumen malas untuk berbelanja di pasar rakyat.

b. Promosi yang menarik

Penjual di pasar rakyatharus bisa bersaing khususnya dari aspek promosi misalnya dengan memberikan potongan-potongan harga untuk konsumen tertentu pada produk-produk yang dijualnya atau memberikan bonus-bonus tertentu kepada pembeli yang sudah menjadi pelanggannya.

c. Pelayanan yang lebih baik

Penjual harus memberikan pelayanan yang lebih baik dan ramah agar konsumenmerasakan kenyamanan berbelanja. Penjual bisa melakukan dengan kekeluargaan agar semakin ada rasa ikatan emosional sehingga konsumentetap setia untuk berbelanja dan selalu kembali berbelanja di tempat yang sama.

d. Strategi diskriminasi harga pada konsumen yang berbeda

Harga menjadi faktor yan sangat sensitif di pasar rakyat. Strategi diskriminasi harga yang dilakukan oleh penjual bisa dilakukan dengan memberikan perbedaan harga bagi konsumen-konsumen yang berbeda, misalnya antara konsumen untuk kebutuhan sendiri/rumah tangga dan konsumen pedagang warung.

e. Kelenturan dalam sistem pembayaran

Penjual seharusnya menerapkan sistem pembayaran yang lentur 
misalnya konsumen melakukan pembayaran baik secara lunas atau hutang dengan perjanjian tertentu.

f. Memperkuat modal sosial yang sudah ada

Adanya modal sosial yang kuat membuat penjual harus memanfaatkan situasi dan kondisi tersebut. Penjual dan konsumen di pasar rakyat relatif telah saling mengenal satu sama lain, berada dalam satu wilayah RT/RW dan bahkan masih saudara. Penjual harus terus menjalin ikatan kekeluargaan dengan baik mislanya dengan memberikan perhatian dalam bentuk; menjenguk saat konsumen sakit, ada pesta perkawinan, sunatan, aktif dalam kegiatan posyandu dan kegiatan sosial lainnya.

\section{PIHAK PENGELOLA}

a. Kerjasama dengan pemerintah dan masyarakat

Pelaksanaan revitalisasi pasar rakyat memerlukan peran serta dari pengelola, masyarakat dan pemerintah. Pengelola pasar harus ikut andil dalam membuat revitalisasi tersebut berhasil dengan berbagai cara diantaranya; melakukan koordinasi denga pihak pusat terkait cara pengelolaan pasar rakyat, (2) melakukan penertiban kepada penjual yang berjualan yang meluap ke bahu jalan-jalan besar atau bahkan berjualan hingga barang dagangan menutupi lorong pasar; (3) menertibkan sampah yang dibuang harus pada tempat sampah; (4) pemberdayaan kepada penjual dengan memberikan sosialiasi dan praktik dalam hal mengelola usaha yang benar dan baik .

b. Manajemen pasar yang profesional dengan merekrut SDM yang berkualitas

Pasar harus dikeola secara baik dan transparan. Bagus atau tidaknya suatu pasar rakyat tergantung dari pengelolapasarnya. Sumber daya manusia/SDM pengelola memainkan peran utama. Kualitas SDM dari pengelola harus ditingkatkan baik 
dari aspek pendidikan, keahlian maupun lainnya. Dengan memiliki profesionalisme yang sangat bagus dalam pengelolaan pasarmaka diharapkan pasar rakyat akan bisa berkembang dan bersaing dengan pasar modern.

c. Pengelola pasar rakyat harus bisa memahami manajemen pasar rakyat dengan baik.

Harus bisa mengelola retribusi, sewa dan pendapatan dengan transparan.

Harus bisa mengelola keuangan pasar dengan sistem pembukuan dan pencatatan yang baik dan transparan, serta sebaiknya mulai ada sistem audit keuangan yang akuntabel.

d. Meningkatkan jalinan hubungan kemitraan yang profesional dengan para pedagang

Hubungan antara pengelola dan pedagang secara umum banyak mendasarkan pada hubungan kekeluargaan dan tidak memiliki ketegasan. Oleh karena itu kedepannya, pengelola pasar dan penjualharus menjalin hubungan kemitraan secara profesional. Hubungan bisa ditindaklanjuti dengan menandatangani perjanjian kerjasama yang memiliki kekuatan hukum dan memberikan manfaat kedua belah pihak sehingga jika ada penjual yang melangggar aturan bisa ditindak dengan tegas.

e. Promosi Pasar Rakyat

Agar pengunjung pasar rakyat semakin banyak dan memiliki kepercayaan kepada pasar rakyat, maka pengelola pasar harus melakukan kegiatan dan tindakan yang positif misalnya promosi. Promosi yang dilakukan sangatlah penting sebagai sarana penyampaian informasi kepada konsumen dan masyarakat tentang beberapa inovasi dan pembaharuan yang telah dan akan dilakukan baik dari aspek produk, layanan dan sarana prasarana.

f. Inkubasi Bisnis dan Teknologi kepada kepada para penjual

Pengelola pasar bisa melakukan inkubasi bisnis dan teknologi kepada penjual agar sama-sama penjualnya 
bisa tumbuh dan berkembang. ketersediaan air bersih dan listrik Inkubasi bisnis dan teknologi yang cukup.

bisadilakukan dengan memberikan i. Pembuatan dan implementasi pelatihan dan pendampingan Dokumen SOP pengelolaan bisnis dan teknologi Pihak pengelola sebaiknya membuat yang bisa digunakan untuk SOP dan mengimplementasikan agar memperlancar kegiatan penjualan di pasar rakyat. Kegiatan ini bisa dilaksanakan tentunya dengan dukungan dari pemerintah daerah dan pusat.

g. Jaminan keamanan pengelolaan pasar bisa mengelola pasarnya dengan lebih nyaman, aman dan sehat. Beberapa SOP yang bisa dibuat diantaranya: SOP Petugas Kebersihan, SOP Petugas Keamanan, SOP Pengelolaan/Pemeliharaan Pasar, SOP Petugas Pasar, SOP Pengelola pasar harus bisa memberikan jaminan keamanaan pasar kepada penjual dan masyarakat agar pasar tidak dikuasai oleh preman-preman pasar yang tidak bertanggung jawab.

h. Jaminan kebersihan dan kesehatan pasar

\section{PIHAK PEMERINTAH}

a. Revitalisasi pasar tradisional

Pengelola pasar harus bisa memberikan jaminan kebersihan dan kesehatan kepada penjual dan masyarakat agar pasar tidak kumuh, bersih dan sehat.Misalnya pengelola pasar harus menjamin adanya 
Indonesia. Tentunya dengan prinsip, prioritas dan kelas tertentu yang ditetapkan oleh pemerintah. Hal ini dilakukan agar masyarakat tetap menyukai berbelanja di pasar rakyat daripada di pasar modern. Lebih jelasnya program revitalisasi pasar rakyat dapat dilihat pada Gambar 1. Program revitaliasi pasar rakyat tersebut di implementasikan dengan berbagai kegiatan seperti yang dapat dilihat pada Gambar 2. 


\section{PROGRAM PEMBANGUNAN/REVITALISASI PASAR RAKYAT}

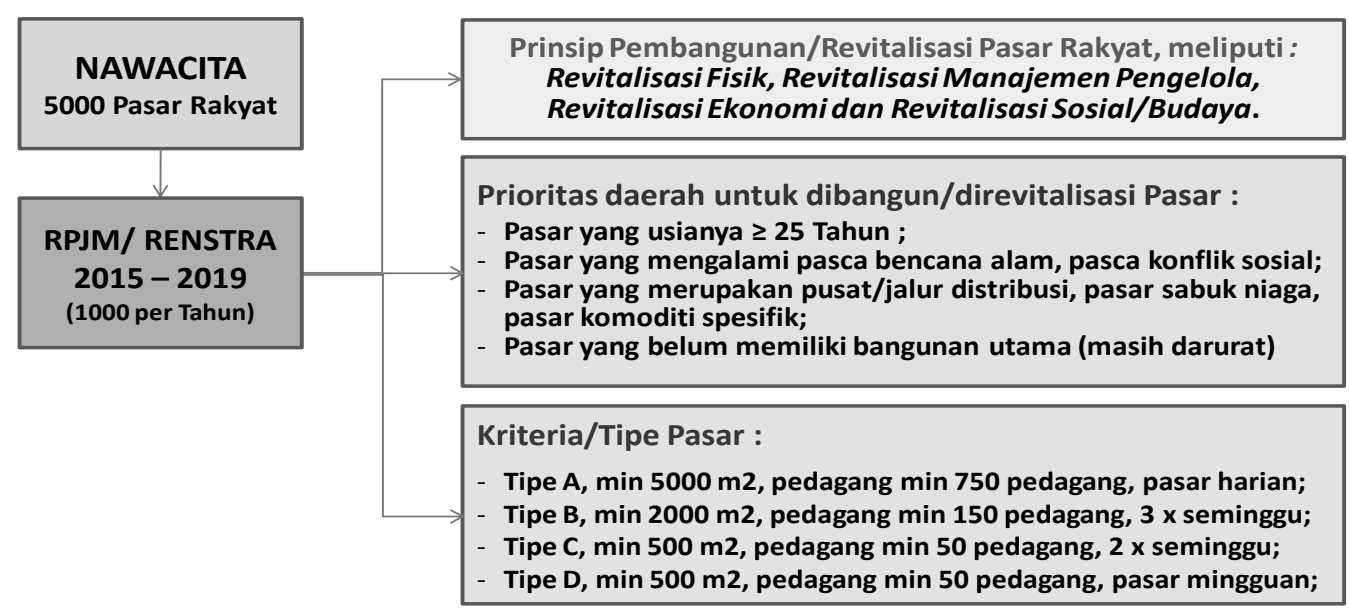

Gambar 1. Program Revitalisasi Pasar Rakyat

Sumber: PaparanDirjenPerdaganganDalamNegeriKementerianPerdagangan

(FGD - Yogyakarta, 30 Maret2017) 


\section{IMPLEMENTASI UU NO 7 TAHUN 2014 TERHADAP KEBIJAKAN PEMBANGUNAN/REVITALISASI PASAR RAKYAT}

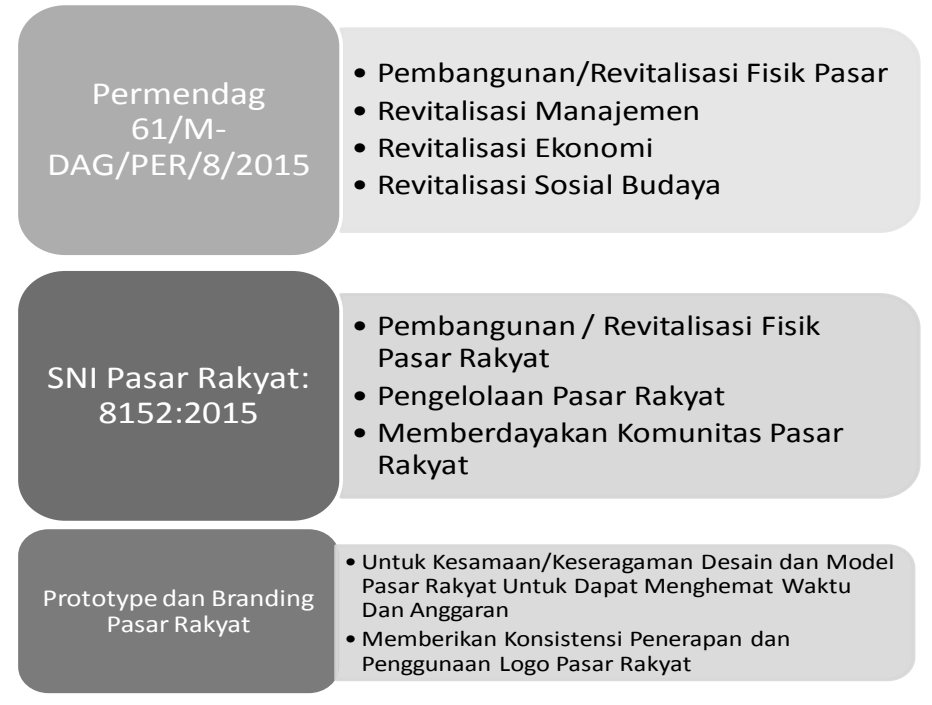

\section{Gambar 2. Implementasi UU No 7 Tahun 2014}

Sumber: PaparanDirjenPerdaganganDalamNegeriKementerianPerdagangan (FGD - Yogyakarta, 30 Maret 2017) 
b. Menjaga kestabilan harga

Pemerintah memiliki kewajiban agar mengatur harga produk-produk yang ditawarkan di pasar rakyat. Harga yang sering berubah dan tidak adanya standar harga yang pasti membuat masyarakat kadangkala bingung dan akhirnya malas untuk berbelanja di pasar rakyat.

c. Regulasi Pasar Modern dan Pasar Rakyat

Regulasi diperlukan agar ada keseimbangan antara pasar rakyat dengan pasar modern, khususnya tentang pendirian, lokasi dan penyediaan barang dagangan produk dalam negeri.

d. Bantuan Modal dan Fasilitas

Dalam pengembangan usaha di pasar rakyat, penjual sangat memerlukan dukungan modal.

Dukungan dari pemerintah kepada penjual atau pedagang di pasar rakyat melalui pemberian pinjaman modal dengan bunga lunak dapat membantu memperbesar usahanya. Disamping pemerintah bisa melakukan fasilitasi dalam hal pelatihan, konsultasi, pasokan barang dan lainnya.

e. Regulasi standarisasiproduk pasar rakyat

Pemerintah perlu untuk membentuk regulasi terkait standar produk yang dijual di pasar rakyat. Hal ini dikarenakan tingkat persaingan yang semakin ketat dalam hal tuntutan konsumen untuk memperoleh produk dengan aman dan higienes sehingga masyarakat memiliki kepercayaan terhadap kualitas produk yang dijual di pasar rakyat tersebut.

\section{PENUTUP}

Berdasarkan hasil FGD tersebut maka dapat diambil kesimpulan bahwa keberadaan pasar modern harus bisa memberikan manfaat bagi semua pihak, khususnya bagi pasar rakyat di Indonesia. Pasar modern dan pasar rakyat harus sama-sama berjalan dan bersinergi satu dengan lainnya. Hasil FGDdiharapkan dapat memberikan manfaat dalam pengembangan ilmu dan pengetahuan yang terkait dengan perumusan strategi dan kebijakan. 
Diharapkan bisa dijadikan alternatif untuk mengimplementasikan

khususnya bagi pelaku usaha, pengelola pasar dan pemerintah sehingga masingmasing bisa saling bersaing secara sehat dan kompetitifserta bersinergi satu sama lain.

\section{DAFTAR PUSTAKA}

Anonim (2008), Peraturan Menteri Perdagangan RI nomor 53 tahun 2008, Pedoman Penataan Dan Pembinaan Pasar Tradisional, PusatPerbelanjaan Dan Toko Modern

Sarwoko, E. (2008). Dampak Keberadaan Pasar Modern terhadap Kinerja Pedagang Pasar Tradisional di Wilayah Kabupaten Malang. Jurnal Ekonomi Modernisasi.

https://doi.org/10.21067/jem.v4i2 .880 .

Suryadarma, D., Poesoro, A., Budiyati, S., Akhmadi dan Rosfadhila, M. (2007), Dampak Supermarket terhadap Pasar dan Pedagang Ritel Tradisional di Daerah Perkotaan di Indonesia, SMERU, Laporan penelitian, p. 1-53.

Susanti, I.A., Darmawan, D.P., dan Astiti, S (2014), Strategi Pengembangan Pasar tradisional Kertha, Desa Kesiman Kertalangu, Kecamatan Denpasar Timur, Jurnal Manajemen Agribisnis, Vol, 2. No. 1, Mei, p. 11-21.
Rahayu, Y., \& Fitanto, B. (2013). Pasar Tradisional Menghadapi Persaingan Dengan Retail Modern Dan Preferensi Konsumen (Studi Kasus Pada Pasar Legi Kota Blitar). Jurnal Ilmiah Mahasiswa FEB. http://jimfeb.ub.ac.id/index.php/ji mfeb/article/view/273

Peraturan Presiden Nomor 112 Tahun 2007 tentang Penataan Dan Pembinaan Pasar Tradisional, Pusat Perbelanjaan Dan Toko Modern.

David, F. (2002), Manajemen Strategis. Konsep, Terjemahan, Edisi Ketujuh, Prenhallindo, Jakarta.

Glueck, W.F and Jauch, L.R. (1991), Strategic Management and Business, Terjemahan, Edisi Kedua, Erlangga, Jakarta.

https://ekbis.sindonews.com/read/103 7133/150/merebaknya-pasarmodern-dan-terpadu-1440556217. akses 1 Agustus 2017. 


\section{BIODATA PENELITI}

\section{Muafi.}

Saat ini sebagai pengajar di FE Universitas Islam Indonesia Prodi Manajemen. Lulus S3 Universitas Brawijaya tahun 2008. Lulus S2 dari Universitas Airlangga tahun 1997. Kompeteensi yang dimiliki Manajemen Sumber Daya Manusia Strategik. Ketua dari dana hibah penelitian dan pengabdian masyarakat dari Kemenristek Dikti untuk Hibah Bersaing, Fundamental, STRANAS. Ketua Riset Implementatif dana Hibah dari LPDP Kemenkeu. Sebagai reviewer penelitian DRPM Dikti dan LPDP Kemenkeu. Sebagai tenaga ahli/konsultan MSDM di berbagai BUMN seperti Perum BULOG dan PT. Pelindo III (Persero). Beberapa paper telah dipublikasikan di Jurnal Internasional bereputasi (Indeks Scopus) dengan perolehan $\mathrm{H}$ index 3. 